\title{
ANALISIS PERBANDINGAN KURIKULUM EKONOMI SMA HONG KONG DENGAN INDONESIA
}

\author{
Roni Faslah*
}

\begin{abstract}
Comparative studies of education is one way of knowing various aspects dealing with education city possessed by country other, especially that dealing with excess happened to the system with the various components fans. Important for us to know education system that owned by a country as a comparison and material academic study against education system that we have. In addition, us to have picture of our own position against sitem are we run. Therefore on that occasion writer trying to untwist comparison education curriculum economic in hongkong with indonesia in secondary high school.
\end{abstract}

\section{PENDAHULUAN}

Sistem pendidikan di Hong Kong merupakan pengembangan sistem pendidikan Inggris. Sebagai tahap awal, orangtua siswa di Hong Kong biasanya menyekolahkan anak mereka di taman kanak-kanak yang dijalani selama tiga tahun. Walaupun bukan bagian dari pendidikan wajib, Pemerintah Hong Kong mengakui taman kanak-kanak memberi dasar pendidikan yang baik. Taman kanakkanak didaftarkan dan diawasi oleh Biro Pendidikan (Education BureauEDB).

Pemerintah Hong Kong menetapkan wajib belajar pada tingkat pendidikan dasar (primary school) yang diselesaikan dalam enam tahun. Kurikulum primary school biasanya meliputi pelajaran inti (bahasa Cina, bahasa Inggris, dan

\footnotetext{
* Roni Faslah. Dosen Fakultas Ekonomi Universitas Negeri Jakarta
}

matematika), pelajaran dasar (ilmu pendidikan sosial dan ilmu pendidikan alam), pelajaran kesehatan, musik, olah raga, dan keterampilan.

Pendidikan wajib berlanjut pada tingkat pendidikan menengah (secondary school) yang dibagi menjadi tiga tahun di tingkat junior secondary dan dua tahun di senior secondary. Tiga tahun pertama di tingkat pendidikan menengah disebut dengan istilah Form One hingga Form Three. Kurikulum pada tingkat ini masih serupa dengan kurikulum pendidikan dasar.

Pada tahap senior secondary, para siswa diminta memilih jurusan mereka yaitu Arts (IPS) dan Science (IPA). Di tingkat Form Four dan Form Five, para siswa mempersiapkan diri untuk mengikuti ujian Hong Kong Certificate of Education Examintaion (HKCEE). Para siswa dengan nilai HKCEE memuaskan dapat melanjutkan ke tahap pendidikan 
menengah berikutnya. Bagi yang mendapat enam nilai A berkesempatan mendaftar Early Admission System (EAS) untuk masuk ke beberapa perguruan tinggi tertentu.

Tahap pendidikan menengah berikutnya tidak menjadi bagian pendidikan wajib dan diselesaikan dalam waktu dua tahun. Form Six dan Form Seven menjadi tahapan terakhir sebelum mengikuti ujian Hong Kong Advanced Level Examination (HKALE). HKALE merupakan ujian yang biasanya menentukan penerimaan seorang siswa di perguruan tinggi. Berdasarkan penelitian OECD siswa sekolah menengah Hong Kong merupakan yang tercemerlang sedunia, peringkat satu di bidang matematika dan peringkat tiga di bidang IPA.

Secara mendasar terdapat empat jenis sekolah di Hong Kong yaitu sekolah negeri, sekolah berbantuan (aided school), sekolah dengan skema subsidi langsung (direct subsidy scheme - DSS) dan sekolah swasta murni. Sekolah negeri dan sekolah berbantuan tidak memungut uang sekolah pada muridmuridnya. Sekolah dengan subsidi langsung hanya menetapkan sedikit biaya pada murid-muridnya. Sekolah swasta murni memungut uang sekolah dengan jumlah yang bervariasi.

Sekolah negeri dan sekolah berbantuan menerapkan kurikulum sesuai dengan standar yang ditetapkan EDB. Sekolah berbantuan biasanya menerima bantuan pemerintah sebanyak 80 persen dari dana operasional yang dibutuhkan dan 20 persen sisanya diperoleh dari organisasi sponsor. Sekolah dengan skema DSS pada dasarnya adalah sekolah swasta nasional yang diberikan dana subsisdi guna makin meningkatkan kualitas pendidikan yang diberikan ke murid. Skema DSS telah diterapkan sejak bulan September 1991 dan dipandang membantu orang tua murid dalam mencari sekolah bagi anak mereka. Sekolah dengan skema DSS juga menerapkan kurikulum standar Hong Kong.

Sekolah swasta murni di Hong Kong menerapkan sistem kurikulum berbeda-beda. Sebagian dari mereka menerapkan sistem pendidikan Inggris dan dikenal sebagai English School Foundation (ESF). Sistem ESF diciptakan pada tahun 1979 guna memenuhi kebutuhan pendidikan Inggris bagi sebagian pelajar di Hong Kong. Selain menerapkan sistem ESF, sebagian sekolah swasta murni juga menerapkan sistem pendidikan dari berbagai negara lain seperti AS, Singapura, Jerman, Kanada, Jepang, dan Korea Selatan. EDB tidak banyak turut campur dalam pendidikan yang ditawarkan oleh sekolah swasta murni.

\section{Kuriklum Ekonomi Hong Kong}

Kurikulum Ekonomi SMA

(Senior secondary/SS) di Hong Kong dirumuskan bersama antara The New Academic Structure for Senior Secondary Education and Higher Education-Action Plan for Investing in the Future of Hong Kong (EMB, 
2005) dan the Senior Secondary Curriculum Guide (SSCG) (CDC, 2007). Kedua dokumen memberikan arah keseluruhan untuk pengembangan pendidikan menengah di Hong Kong. Mereka menetapkan kombinasi inti dan pilihan mata pelajaran, pelaksanaan pembelajaran dan pengalaman belajar lainnya sesuai dengan minat dan bakat siswa.

Ekonomi adalah salah satu dari enam mata pelajaran yang terdapat pada the Personal, Social and Humanities Education (PSHE) Key Learning Area (KLA) yang diselenggarakan selama 3 tahun. Studi ekonomi membantu siswa untuk memahami dunia manusia melalui penyelidikan bagaimana sumber daya digunakan untuk melayani individu dan masyarakat. Hal ini juga memberikan kontribusi terhadap pengembangan pemikiran kritis dan ketrampilan dalam pengambilan keputusan, yang sangat penting untuk perkembangan siswa dan, khususnya, perkembangan mereka sebagai pembelajar seumur hidup dan menjadi warga Negara yang bertanggung jawab.

\section{Tujuan Kurikulum Ekonomi SMA Hong Kong}

Tujuan Kurikulum Dalam Aspek Pengetahuan dan pemahaman

Siswa akan mengembangkan pengetahuan dan pemahaman tentang:

(A) terminologi dan konsep-konsep ekonomi, serta teori-teori dasar ekonomi;
(B) masalah dasar ekonomi yang dihadapi oleh setiap individu dan masyarakat, dan alternatif pendekatan untuk mengatasi masalah ini;

(C) pertimbangan dan kekuatan yang mendasari keputusan ekonomi yang perlu diambil oleh individu, perusahaan, lembaga dan pemerintah;

(D) interaksi sektor ekonomi yang berbeda, dan

(E) ekonomi Hong Kong dan hubungannya dengan ekonomi bagian lain dari bangsa dan dunia.

\section{Tujuan Kurikulum Dalam Aspek Keterampilan}

Siswa akan mengembangkan keterampilan untuk:
(A) menginterpretasikan informasi ekonomi yang disajikan secara verbal, bentuk numerik atau grafis;
(B) menerapkan pengetahuan ekonomi mereka ke dalam berbagai konteks masalah dan isu ekonomi;
(C) menganalisis informasi melalui penggunaan konsep-konsep dan teori ekonomi;
(D) mengevaluasi informasi, argumen, usulan, dan kebijakan dari perspektif ekonomi yang berbeda dan membuat analisis informasi, dan
(E) mengkomunikasikan ide-ide ekonomi dan analisis informasi, secara jelas, logis dan objektif.

Tujuan Kurikulum Dalam Aspek Nilai dan sikap 
Siswa akan mengembangkan nilai-nilai dan sikap sehingga mereka dapat:

(A) berpartisipasi sebagai penyedia informasi dalam pembahasan isu-isu ekonomi dan keputusankeputusan; dan

(B) menjadi warga negara yang aktif dan bertanggung jawab dan berkontribusi terhadap kesejahteraan masyarakat lokal, bangsa dan dunia

\section{Outcomes Pembelajaran Ekonomi}

Setelah mempelajari ekonomi, siswa memiliki kemampuan sebagai pengambil kebijakan/keputusan ekonomi dan mampu menunjukkan:

a) pemahaman tentang kelangkaan, pilihan dan biaya sebagai dasar dari masalah ekonomi;

b) kemampuan untuk mengenali peran spesialisasi dan pertukaran produktivitas di dalam pertumbuhan ekonomi;

c) pemahaman tentang bagaimana cara pengambilan keputusan mengenai produksi , pertukaran dan konsumsi, dan terkait masalah koordinasi, yang ditangani oleh harga dan metode non harga dari alokasi dana, dan implikasi dari metode alokasi dana ini;

d) kemampuan dalam menerapkan model dasar penawaranpermintaan untuk menjelaskan peristiwa yang terjadi dalam dunia nyata, dengan memperluas analisis ini, untuk mempelajari efisiensi dengan menggunakan surplus konsumen dan/atau surplus produser;

e) kemampuan untuk menafsirkan fluktuasi output, pekerjaan dan tingkat harga umum dalam perekonomian yang menggunakan kerangka kerja aggregate supply-aggregate demand (AS-AD) dan teori jumlah uang;

f) apresiasi tentang hubungan antara pembelajar dan / lingkungan sosialnya pada saat ini dan waktu yang tepat, yang dikembangkan melalui pemahaman berbagai lembaga ekonomi, peristiwa, dan aturan;

g) kemampuan untuk menyusun data ekonomi dan representasi yang berbeda (misalnya grafik) untuk memeriksa dan menafsirkan bukti dalam menjelaskan pola-pola sosial dan peristiwa-peristiwa dengan menggunakan alat analisis ekonomi;

h) kompetensi dalam keterampilan generik seperti keterampilan komunikasi, keterampilan pemecahan masalah dan keterampilan berpikir kritis melalui penyelidikan isu-isu ekonomi dan yang kontroversial, dan

i) orientasi dan kompetensi dalam menggunakan teknologi informasi dan komunikasi untuk pembelajaran inkuiri dan konstruksi pengetahuan

$\begin{array}{lll}\text { Prinsip Dalam } & \text { Mendesain } \\ \text { Kurikulum Ekonomi } & \text { SMA Hong } \\ \text { Kong } & & \end{array}$ 
Prinsip-prinsip dalam mendesain kurikulum ini didasarkan pada rekomendasi The New Academic Structure for Senior Secondary Education and Higher EducationAction Plan for Investing in the Future of Hong Kong (EMB, 2005) yang direkomendasikan dalam Bab 3, yaitu bahwa kurikulum ini harus:
(A) membangun pengetahuan, keterampilan, nilai dan sikap, dan pengalaman belajar yang telah diperoleh dan dikembangkan oleh siswa melalui pembelajaran yang terdapat dalam kurikulum PSHE pada pendidikan dasar;

(B) mencapai keseimbangan yang luas dan mendalam dalam studi ekonomi dalam memfasilitasi siswa untuk persiapan studi lebih lanjut, masuk ke dalam angkatan kerja dan menjadi pribadi yang utuh dalam pembangunan;

(C) mencapai keseimbangan antara belajar pengetahuan teoritis dan aplikasi dalam situasi kehidupan nyata. Penekanan yang sama harus diberikan untuk pengembangan pengetahuan secara sistematis dan konseptual di bidang ekonomi, dan pemahaman yang lebih baik tentang isu-isu ekonomi dan masalah yang relevan dengan kehidupan sekarang dan masa depan siswa;

(D) menyediakan kerangka kerja yang fleksibel dan beragam yang mampu melayani pelajar dalam keragaman kemampuan, kebutuhan dan kepentingan. Pilihan elemen kurikulum harus mengarah ke belajar secara efektif dan mudah untuk semua siswa dalam mempelajari Ekonomi, sehingga keberhasilan dalam belajar dapat direalisasikan untuk semua orang;

(E) membantu siswa untuk mengembangkan keterampilan belajar mandiri dan seumur hidup dengan mendorong inkuiri yang berpusat pada siswa;

(F) mendorong eksplorasi isu-isu sosial. Penanaman nilai-nilai, berbagai perspektif dan empati harus ditekankan dalam kurikulum ini, dan

(G) menyelaraskan kurikulum dan penilaian yang ketat, dengan penilaian yang dirancang sebagai bagian integral dari proses belajar dan mengajar

Untuk meningkatkan pendekatan yang lebih berpusat pada siswa, guru didorong untuk menggunakan strategi berikut ini dalam menyusun perencanaan kuriklum:

1. Mengintegrasikan pembelajaran di kelas dan belajar mandiri

Di dalam kelas, guru dapat memberikan kesempatan belajar yang luas bagi setiap siswa. Untuk manfaat jangka panjang dari siswa, guru harus mendorong siswa untuk menjadi pembelajar mandiri. Guru dapat menumbuhkan motivasi intrinsik pada siswa melalui upaya sadar dengan menggunakan kasus- 
kasus otentik dan melalui pengamatan sehingga penjelasan pembelajaran ekonomi menjadi lebih menarik. Guru harus merancang tugas-tugas belajar yang bermakna di dalam dan di luar kelas. Sekolah dapat mempertimbangkan memiliki panduan yang lebih eksplisit tentang cara-cara meminimalkan pembelajaran hafalan dan meningkatkan kompetisi di antara peserta didik secara individu dalam rencana kurikulum.

2. Keragaman peserta didik

Siswa memiliki karakteristik dalam keluarga mereka, latar belakang sosial, ekonomi dan budaya, dan memiliki yang bakat dan minat berbeda. Kurikulum Ekonomi Sekolah menengah senior dirancang sedemikian rupa bahwa konsepkonsep dasar dan alat analisis ditanamkan di Bagian Wajib, sedangkan bagian elektif meliputi unsur-unsur pengetahuan ekonomi yang meliputi analisis lebih lanjut dan lebih luas. Siswa dapat memilih salah satu yang sesuai minat dan bakat mereka. Mereka yang tertarik dalam analisis mikroekonomi seperti strategi harga perusahaan mungkin dapat memilih Pilihan Bagian 1. sedangkan, siswa yang tertarik dalam ekonomi makro, kinerja dan pertumbuhan ekonomi dapat memilih pilihan 2 Bagian elektif. Selain itu, Kurikulum telah mencadangkan waktu pelajaran bagi siswa untuk melakukan kegiatan penyelidikan. Mereka mungkin memilih masalah penyelidikan yang paling sesuai dengan minat mereka.
Di dalam kelas, siswa memiliki perberbedaan dalam tingkat perhatian dan kemampuan mereka untuk menerima dan menafsirkan pesan. Guru didorong untuk mengadopsi berbagai pendekatan belajar dan mengajar. Misalnya, selain instruksi langsung, guru juga dapat melibatkan siswa dalam tugastugas, berkomunikasi dengan teman sebaya, mempresentasikan ide-ide, mengomentari kegiatan sosial, menggambar diagram untuk ide di papan tulis, melakukan pencarian di internet, dll sehingga siswa dapat mengembangkan kekuatan mereka dalam tugas-tugas ini dan memperoleh kepercayaan diri, merasakan kompetensi dan keberhasilan.

3. Membangun sebuah komunitas pembelajaran di antara para siswa

Konsep masyarakat belajar juga harus dipertimbangkan dalam perencanaan kurikulum. Siswa harus diberikan tugas-tugas yang melibatkan kolaborasi melalui diskusi kelompok dalam pemecahan masalah. Guru harus memantau dan memfasilitasi kerja siswa dengan memberikan bimbingan pada waktu yang tepat. Membangun komunitas belajar antara siswa harus menjadi salah satu target guru dalam perencanaan pembelajaran Ekonomi.

4. Feksibilitas pengorganisasian
kelas

Guru harus mengekplorasi kelas secara fleksibel penggunaan waktu dan sumber daya sekolah 
dengan dua atau lebih kelas Ekonomi pada satu tingkat. Kegiatan belajar dalam kelompok besar dapat dikombinasikan dengan les kelompok kecil dengan jumlah guru yang sama. Sebagai contoh, blok timetabling memungkinkan fleksibilitas dalam penyebaran staf untuk kegiatan belajar bervariasi. Dalam blok sore, dua kelas mungkin terlibat dalam proyek penyelidikan dengan dukungan dua

guru dan dua asisten pengajar, dan dalam siklus berikutnya, blok yang sama dapat digunakan untuk kuliah atau kelompok kegiatan belajar di ruang sekolah, cukup diperlukan satu guru Ekonomi. Pengaturan ini, dapat digunakan bersama dengan mata pelajaran lainnya, dapat memberikan lebih banyak variasi dalam kegiatan belajar dengan staf pengajar yang sama.

\section{Perencanaan Cros-kurikuler} Untuk memaksimalkan belajar siswa, kerjasama dengan mata pelajaran lain juga harus dipertimbangkan. Sebagai contoh, studi tentang efisiensi dan isu-isu kesetaraan dalam polusi dapat memperkuat studi Geografi. Banyak pendekatan terhadap isu-isu sosial permintaan multi-disiplin wawasan. Untuk memperkaya pengalalman belajar guru dapat merancang tugastugas seperti proyek-proyek penyelidikan tentang "Flu Burung dan obat yang dipatenkan"di mana guru bekerja dengan Ekonomi atau guru bidang Studi Biologi. Ini akan menunjukkan bahwa batas-batas subjek tidak boleh dibatasi dalam siswa belajar. Keterkaitan antar konsep yang sama melalui konteks yang berbeda atau tampaknya tidak berhubungan pada subyek akan memiliki dampak yang kuat pada siswa, dan bermanfaat bagi guru.

Sistematis kolaborasi antara mata pelajaran untuk mendorong koherensi yang lebih besar antara Ekonomi dan mata pelajaran lain dapat dipertimbangkan ketika kondisi untuk melakukannya menguntungkan. Kolaborasi dalam merancang unit lintas-kurikuler dapat menjadi titik awal

6. Sinkronisasi bagian konten dengan kesempatan belajar otentik

Guru dapat mengambil keuntungan dari peristiwa sosial atau publik yang secara langsung berhubungan dengan konten Ekonomi. Sebagai contoh, pengumuman pemerintah mengenai anggaran tahunan pada bulan Februari ini terkait dengan topik tentang perpajakan, dan peluang bisnis untuk publik dalam bazar di taman publik utama sebelum Tahun Baru Imlek, peristiwa ini melibatkan konsep dalam topik pada bisnis kepemilikan dan struktur pasar. Keselarasan dari kesempatan ini dengan waktu penyampaian komponen konten yang relevan akan meningkatkan belajar siswa.

7. Mengintegrasikan pembelajaran dengan penilaian

Belajar harus didukung oleh penilaian, dan penilaian tugas-tugas seperti menulis sebuah jurnal 
reflektif, dapat menjadi bagian dari belajar. Guru harus menempatkan lebih menekankan pada peran penilaian berkelanjutan dan formatif dalam memberikan umpan balik kepada siswa untuk perbaikan.

Tabel 1

Alokasi Waktu

\begin{tabular}{|l|c|}
\hline \multicolumn{1}{|c|}{ Topic } & $\begin{array}{c}\text { Suggested lesson time } \\
\text { (hours) }\end{array}$ \\
\hline A Basic Economic Concepts & 12 \\
\hline B Firms and Production & 30 \\
\hline C Market and Price & 32 \\
\hline D Competition and Market Structure & 8 \\
\hline E Efficiency, Equity and the Role of Government & 18 \\
\hline F Measurement of Economic Performance & 12 \\
\hline G National Income Determination and Price Level & 16 \\
\hline H Money and Banking & 18 \\
\hline I Macroeconomic Problems and Policies & 30 \\
\hline J International Trade and Finance & 18 \\
\hline $\begin{array}{l}\text { Elective Part 1: Monopoly Pricing, Anti-competitive } \\
\text { Behaviours and Competition Policy; OR } \\
\text { Elective Part 2: Extension of Trade Theory, Economic } \\
\text { Growth and Development }\end{array}$ & 22 \\
\hline Sub-Total & \\
\hline $\begin{array}{l}\text { Suggested time allocation for conducting learning } \\
\text { activities such as news commentary and other enquiry } \\
\text { activities }\end{array}$ & 216 \\
\hline Total & 54 \\
\hline
\end{tabular}

\section{Pengelolaan Kurikulum Ekonomi SMA Hong Kong}

Dalam mengelola kurikulum sekolah menengah Ekonomi, guru harus mempertimbangkan hal-hal berikut:

(A) Memahami kurikulum dan konteks pembelajaran
a) memahami Panduan Kurikulum Menengah (CDC, 2007) dan Panduan dengan tujuan untuk mengadaptasi kurikulum pusat

untuk sekolah berbasis pengembangan kurikulum;

b) mempertimbangkan budaya masyarakat dan perubahan kebutuhan masyarakat

c) membuat referensi ke visi dan misi sekolah, kekuatan dan kebijakan, serta kemampuan dan kepentingan siswa, untuk keputusan-keputusan kurikulum utama;

d) memiliki visi bersama tentang pendidikan ekonomi dan 
pemahaman yang jelas tentang tujuan, tujuan dan hasil pembelajaran dari kurikulum Ekonomi, dan

e) berkomitmen dan antusias dalam berkolaborasi dengan rekan-rekan dalam enciptakan lingkungan budaya positif bagi siswa untuk membangun pengetahuan secara mandiri dan kolaboratif.

(B) Perencanaan dan pelaksanaan kurikulum

a) desain dan menerapkan skema kerja untuk membantu siswa untuk mencapai tujuan kurikulum dan tujuan pembelajaran dari kurikulum Ekonomi;

b) desain mode penilaian dan tugas untuk mempromosikan penilaian untuk belajar;

c) desain pembelajaran yang tepat dan urutan pengajaran yang terbaik akan memenuhi kebutuhan siswa dan meningkatkan kemajuan mereka dan prestasi dalam belajar;

d) eksplisit mengartikulasikan generasi dan konsolidasi pengetahuan profesional guru; dan

e) mengembangkan belajar kolaboratif dan budaya pengajaran untuk meningkatkan efektiitas pembelajaran. Guru dapat mempertimbangkan berbagai kemungkinan, seperti:

- mengembangkan budaya timmengajar dalam rangka untuk berbagi pengalaman mengajar;

- menciptakan kesempatan belajar dan berbagi melalui jaringan dengan sekolah lain; dan

- menjelajahi pengaturan

penjadwalan yang

memungkinkan pembelajaran kolaboratif atau pengembangan profesional di kalangan guru.

(C) Mengevaluasi kurikulum

a) meningkatkan pelaksanaan kurikulum Ekonomi dengan terus menerus melalui penelitian tindakan, berkolaborasi dengan rekan atau ahli, dll;

b) meninjau kurikulum secara teratur sesuai dengan konteks belajar dan mengajar dan membuat penyesuaian bila diperlukan;

c) membangun sistem evaluasi kurikulum dengan partisipasi penuh guru dan kepemilikan, dan merekam bukti dan prestasi belajar siswa, dan

d) dukungan siswa dalam merefleksikan, mengatur dan mengendalikan pembelajaran mereka sendiri melalui desain aktivitas kelas yang menciptakan belajar aktif.

(D) Mengembangkan sumber belajar dan mengajar

a) mengembangkan, mengumpulkan dan mengatur sumber daya belajar dan mengajar seperti artikel, laporan, video dan perangkat lunak untuk belajar siswa dan referensi guru, dan menyediakan akses yang mudah untuk siswa; 
b) mengefektifkan sumber daya sekolah dan masyarakat untuk memfasilitasi belajar siswa, dan

c) memperluas belajar dan sumbersumber pengajaran melalui penggunaan informasi dan teknologi komunikasi.

\section{Peran stakeholder yang berbeda}

(A) guru Ekonomi

a) mengikuti perubahan terbaru dalam kurikulum, strategi pembelajaran dan pengajaran dan praktek penilaian;

b) berkontribusi terhadap pelaksanaan pembangunan kurikulum Ekonomi, dan evaluasi, dan menyarankan strategi untuk belajar, mengajar dan penilaian;

c) mengembangkan students'potential dalam pembelajaran ekonomi, dan mendorong mereka untuk belajar secara aktif;

d) berpartisipasi aktif dalam pengembangan profesional, kolaborasi rekan dan pertukaran profesional, dan

e) berpartisipasi dalam penelitian pendidikan dan proyek-proyek dalam rangka memberikan kontribusi untuk belajar dan mengajar Ekonomi

B) koordinator PSHE KLA dan ketua panel Ekonomi
a) memimpin dan rencana pengembangan kurikulum Ekonomi, dan menetapkan arah yang jelas untuk itu;
b) memantau pelaksanaan kurikulum, dan membuat penyesuaian yang tepat dalam

strategi untuk belajar, mengajar dan penilaian, dengan pertimbangan untuk ' kebutuhan siswa

c) memfasilitasi pengembangan profesional oleh anggota panel mendorong untuk berpartisipasi dalam kursus pelatihan dan lokakarya;

d) mengadakan pertemuan formal dan informal dengan anggota panel untuk memperkuat koordinasi dan komunikasi di antara mereka;

e) mempromosikan pertukaran profesional pada pengetahuan subjek dan strategi belajar dan mengajar; dan

f) membuat penggunaan terbaik dari sumber daya yang tersedia di sekolah dan masyarakat

(C) Orang tua

a) mendukung pengembangan kurikulum Ekonomi;

b) mendorong anak-anak mereka untuk belajar lebih banyak tentang fenomena sosial atau ekonomi, terutama melalui media, untuk meningkatkan kesadaran dan kepekaan;

c) secara aktif berkomunikasi dengan anak-anak mereka pada isu-isu ekonomi yang mereka minati; dan

d) memahami nilai pendidikan ekonomi, dan mendorong dan mendukung anak-anak mereka dalam belajar. 


\section{Kurikulum Ekonomi SMA Indonesia \\ Dasar Pemikiran Kurikulum Ekonomi SMA di Indonesia}

Ekonomi merupakan ilmu tentang perilaku dan tindakan manusia untuk memenuhi kebutuhan hidupnya yang bervariasi, dan berkembang dengan sumber daya yang ada melalui pilihan-pilihan kegiatan produksi, konsumsi, dan/atau distribusi. Luasnya ilmu ekonomi dan terbatasnya waktu yang tersedia membuat standar kompetensi dan kompetensi dasar ini dibatasi dan difokuskan kepada fenomena empirik ekonomi yang ada disekitar peserta didik, sehingga peserta didik dapat merekam peristiwa ekonomi yang terjadi disekitar lingkungannya dan mengambil manfaat untuk kehidupannya yang lebih baik.

Pembahasan manajemen difokuskan pada fungsi manajemen badan usaha dalam kaitannya dengan perekonomian nasional. Pembahasan fungsi manajemen juga mencakup pengembangan badan usaha termasuk koperasi.

Akuntansi difokuskan pada perilaku akuntansi jasa dan dagang. Peserta didik dituntut memahami transaksi keuangan perusahaan jasa dan dagang serta mencatatnya dalam suatu sistem akuntansi untuk disusun dalam laporan keuangan. Pemahaman pencatatan ini berguna untuk memahami manajemen keuangan perusahaan jasa dan dagang.

Mata pelajaran Ekonomi diberikan pada tingkat pendidikan dasar sebagai bagian integral dari IPS. Pada tingkat pendidikan menengah, ekonomi diberikan sebagai mata pelajaran tersendiri.

\section{Fungsi dan Tujuan Kurikulum Ekonomi SMA Indonesia}

a. Fungsi

Fungsi mata pelajaran ekonomi adalah mengembangkan kemampuan siswa untuk berekonomi, dengan cara mengenal berbagai kenyataan dan peristiwa ekonomi, memahami konsep dan teori serta berlatih dalam memecahkan masalah ekonomi yang terjadi di lingkungan masyarakat.

b. Tujuan

Mata pelajaran Ekonomi bertujuan agar peserta didik memiliki kemampuan sebagai berikut.

1. Memahami sejumlah konsep ekonomi untuk mengkaitkan peristiwa dan masalah ekonomi dengan kehidupan sehari-hari, terutama yang terjadi dilingkungan individu, rumah tangga, masyarakat, dan negara

2. Menampilkan sikap ingin tahu terhadap sejumlah konsep ekonomi yang diperlukan untuk mendalami ilmu ekonomi

3. Membentuk sikap bijak, rasional dan bertanggungjawab dengan memiliki pengetahuan dan keterampilan ilmu ekonomi, manajemen, dan akuntansi yang bermanfaat bagi diri sendiri, rumah tangga, masyarakat, dan negara

4. Membuat keputusan yang bertanggungjawab mengenai 
nilai-nilai sosial ekonomi dalam masyarakat yang majemuk, baik dalam skala nasional maupun internasional

\section{Ruang Lingkup}

Ruang lingkup mata pelajaran ekonomi di SMA dan MA dimulai dari masalah-masalah ekonomi yang terjadi di lingkungan kehidupannya yang terdekat hingga pada lingkungan yang terjauh. Adapun ruang lingkup pelajaran ekonomi di SMA dan MA adalah perilaku ekonomi dan kesejahteraan yang secara rinci mencakup aspek-aspek sebagai berikut:

1. Berekonomi.

2. Ketergantungan.

3. Spesialisasi dan pembagian kerja.

4. Perkoperasian.

5. Kewirausahaan.

6. Pengelolaan keuangan perusahaan.

\section{Standar Kompetensi Lintas Kurikulum}

Kompetensi Lintas Kurikulum merupakan kecakapan untuk belajar sepanjang hayat sebagai akumulasi kemampuan setelah seseorang mempelajari berbagai kompetensi dasar yang dirumuskan setiap mata pelajaran.

Kompetensi Lintas Kurikulum tersebut dirumuskan menjadi sembilan kompetensi sehingga siswa mampu:

1. Memiliki keyakinan, mempunyai hak, menjalankan kewajiban dan berperilaku sesuai dengan agama yang dianutnya, serta menyadari bahwa setiap orang perlu saling menghargai dan merasa aman.
2. Menggunakan bahasa untuk memahami, mengembangkan, dan mengkomunikasikan gagasan dan informasi, serta untuk berinteraksi dengan orang lain.

3. Memilih, memadukan, dan menerapkan konsep-konsep dan tekni-kteknik numerik dan spasial, serta mampu mencari dan menyusun pola, struktur, dan hubungan.

4. Memilih, mencari, dan menerapkan teknologi dan informasi yang diperlukan dari berbagai sumber serta menilai kebermanfaatannya.

5. Memahami dan menghargai dunia fisik, makhluk hidup, dan teknologi, dan menggunakan pengetahuan, keterampilan, dan nilai-nilai untuk mengambil keputusan yang tepat.

6. Memahami konteks budaya, geografi, dan sejarah, serta memiliki pengetahuan, keterampilan, dan nilai-nilai untuk berpartisipasi aktif dalam kehidupan, serta berinteraksi dan berkontribusi dalam masyarakat dan budaya global.

7. Berpartisipasi dalam kegiatan kreatif di lingkungan untuk saling menghargai karya artistik, budaya, dan intelektual serta menerapkan nilai-nilai luhur untuk meningkatkan kematangan pribadi menuju masyarakat beradab.

8. Menunjukkan kemampuan berpikir konsekuen, berpikir lateral, berpikir kritis, memperhitungkan peluang dan potensi, serta siap untuk 
menghadapi berbagai kemungkinan.

9. Menunjukkan motivasi dan percaya diri dalam belajar, mampu bekerja mandiri, dan mampu bekerja sama dengan orang lain.

\section{Standar Kompetensi Bahan Kajian}

1. Kemampuan memahami fakta, konsep, dan generalisasi tentang sistem sosial dan budaya dan menerapkannya untuk:

a. Mengembangkan sikap kritis dalam situasi sosial yang timbul sebagai akibat perbedaan yang ada di masyarakat.

b. Menentukan sikap terhadap proses perkembangan dan perubahan sosial budaya.

c. Menghargai keanekaragaman sosial budaya dalam masyarakat multikultur.

2. Kemampuan memahami fakta, konsep, dan generalisasi tentang manusia, tempat, dan lingkungan dan menerapkannya untuk:

a. Menganalisis proses kejadian, interaksi dan saling ketergantungan antara gejala alam dan kehidupan di muka bumi dalam dimensi ruang dan waktu.

b. Terampil dalam memperoleh, mengolah, dan menyajikan informasi geografis.

3. Kemampuan memahami fakta, konsep, dan generalisasi tentang perilaku ekonomi dan kesejahteraan dan menerapkannya untuk:
a. Berperilaku yang rasional dan manusiawi dalam memanfaatkan sumber daya ekonomi.
b. Menumbuhkan jiwa, sikap, dan perilaku kewirausahaan.
c. Menganalisis sistem informasi keuangan lembaga-lembaga ekonomi.
d. Terampil dalam praktik usaha ekonomi sendiri.

4. Kemampuan memahami fakta, konsep, dan generalisasi tentang waktu, keberlanjutan dan perubahan dan menerapkannya untuk:
a. Menganalisis keterkaitan antara manusia, waktu, tempat, dan kejadian.
b. Merekonstruksi masa lalu, memaknai masa kini, dan memprediksi masa depan.
c. Menghargai berbagai perbedaan serta keragaman sosial, kultural, agama, etnis, dan politik dalam masyarakat dari pengalaman belajar peristiwa sejarah.

5. Kemampuan memahami dan menginternalisasi sistem berbangsa dan bernegara dan menerapkannya untuk:
a. Mewujudkan persatuan bangsa berdasarkan Pancasila dan UUD 1945.
b. Membiasakan untuk mematuhi norma, menegakkan hukum, dan menjalankan peraturan. mewujudkan masyarakat dan pemerintahan yang
c. Berpartisipasi dalam demokratis, menjunjung 
tinggi, melaksanakan, dan menghargai HAM.

\section{Standar Kompetensi Mata Pelajaran}

1. Kemampuan memahami perilaku pelaku ekonomi dalam kaitannya dengan kelangkaan, pengalokasian sumber daya dan barang, melalui mekanisme pasar.

2. Kemampuan memahami konsep ekonomi kemasyarakatan dan kebijakan pemerintah dalam bidang ekonomi.

3. Kemampuan memahami perekonomian internasional, sistem ekonomi Indonesia, manajemen, pembangunan ekonomi, tenaga kerja, wirausaha dan model pemecahan masalah ekonomi.

\section{Rambu-rambu}

1. Kurikulum Berbasis Kompetensi merupakan pedoman bagi pengembang kurikulum di daerah untuk menyusun silabus yang akan digunakan oleh guru dalam melaksanakan tugas mengelola proses belajar mengajar di sekolah.

2. Pemahaman pengembang kurikulum di daerah terhadap Kurikulum Berbasis Kompetensi merupakan syarat mutlak agar dapat menyusun silabus sesuai dengan kebutuhan daerah.

3. Kurikulum Berbasis Kompetensi berbentuk matrik yang meliputi:
a. Standar Kompetensi
b. Kompetensi dasar
c. Indikator

d. Materi Pokok

Standar Kompetensi adalah pernyataan yang mencakup pengetahuan, keterampilan, sikap, dan nilai yang direfleksikan dalam kebiasaan bertindak dan berfikir setelah siswa menyelesaikan suatu aspek atau sub aspek mata pelajaran dalam satu kelas.

Kompetensi Dasar merupakan pernyataan minimal atau memadai tentang pengetahuan, keterampilan, sikap dan nilai-nilai yang direfleksikan dalam kebiasaan berpikir dan bertindak setelah siswa menyelesaikan suatu aspek atau subaspek mata pelajaran tertentu.

Indikator merupakan kompetensi dasar secara spesifik yang dapat dijadikan ukuran untuk menilai ketercapaian hasil pembelajaran.

4. Pelajaran ekonomi termasuk didalamnya pelajaran akuntansi, sehingga pembagian jam pelajaran ekonomi seperti berikut:
a. Kelas X, 2 jam : Ekonomi 2 jam, Akuntansi (tidak ada)
b. Kelas XI, 5 jam : Ekonomi 3 jam, Akuntansi 2 jam
c. Kelas XII, 5 jam : Ekonomi 3 jam, Akuntansi 2 jam

5. Kompetensi Dasar yang sudah diperoleh oleh siswa di SMP tidak lagi diajarkan di SMA, oleh karena itu guru perlu mengingatkan kembali cakupan kompetensi tersebut pada kompetensi yang relevan.

6. Pembelajaran ekonomi di SMA dan MA menggunakan 
pendekatan pemecahan masalah dimana siswa dapat memecahkan masalahmasalah ekonomi di masyarakat terutama dalam mencari alternatif pemecahannya. Agar pembelajaran lebih bermakna maka penyajian materi di mulai dari mengidentifikasi fakta tentang peristiwa dan permasalahan ekonomi, pemahaman beberapa konsep dan ilmu dasar ekonomi, mencari alternatif pemecahan masalah ekonomi serta menilai kebaikan dan keburukan kebijakan pemerintah dalam mengatasi masalah ekonomi.

7. Dalam pembelajaran ekonomi perlu diikuti dengan praktek berekonomi. Praktek ini merupakan suatu inovasi pembelajaran yang dirancang untuk membantu siswa agar memahami fakta, peristiwa, konsep, dan generalisasi melalui pengalaman belajar praktek empirik. Adapun salah satu contoh tema adalah praktek usaha ekonomi sendiri, misalnya membuka warung, praktek di koperasi atau beternak yang produktif.

8. Penilaian hendaknya tidak hanya dilakukan sesaat, akan tetapi harus dilakukan secara berkala dan berkesinambungan. Di samping itu penilaian bukan hanya menaksir sesuatu secara parsial, melainkan harus menaksir sesuatu secara menyeluruh yang meliputi proses, hasil dan perkembangan wawasan pengetahuan, sikap, dan keterampilan yang dicapai siswa. Oleh karena itu hendaknya dikembangkan sistem penilaian yang berbasis portofolio (portfolio based assessment), yaitu suatu usaha untuk memperoleh berbagai informasi secara berkala, berkesinambungan, dan menyeluruh, tentang proses dan hasil pertumbuhan dan perkembangan wawasan pengetahuan, sikap, dan keterampilan peserta didik yang bersumber dari catatan dan dokumentasi pengalaman belajarnya. Misalnya, untuk menentukan nilai rapor siswa, seorang guru menyimpulkannya dari hasil ulangan harian, ulangan umum, tugas-tugas terstruktur, catatan perilaku harian siswa (anecdotal record), dan laporan kegiatan siswa di luar sekolah yang menunjang kegiatan belajar. Semua indikator proses dan hasil belajar siswa itu dicatat dan didokumentasikan.

9. Dalam pembelajaran ekonomi dapat menggunakan berbagai media yang mempunyai potensi untuk menambah wawasan dan konteks belajar serta meningkatkan hasil belajar. Slide, film, radio, televisi, dan komputer yang dilengkapi dengan CD-Room dan hubungan internal dapat dimanfaatkan untuk mengakses berbagai informasi isu-isu lokal, nasional, dan internasional.

\section{PENUTUP}

$\begin{array}{rrr}\text { Dalam } & \text { kuikulum } & \text { ekonomi } \\ \text { Hong } \quad \text { Kong, selain tujuan }\end{array}$


pembelajaran secara umum, pada kurkulum ini juga sudah dirinci sesuai dengan ranah tujuan pembelajaran yaitu tujuan (1) tujuan kurikulum dalam aspek pengetahuan dan pemahaman, (2) tujuan kurikulum dalam aspek keterampilan, dan (3) tujuan kurikulum dalam aspek nilai dan sikap. Disamping tujuan, pada kurikulum inipun dicantumkan outcome yang akan diperoleh siswa setelah menyelesaikan studi yaitu siswa memiliki kemampuan sebagai pengambil kebijakan/keputusan ekonomi. Sedangkan pada kurikulum Ekonomi Indonesia, tujuan kurikulum tidak dirinci berdasarkan aspek-aspek tersebut. Kurikulum ekonomi Indonesia tidak mencantumkan outcome, tetapi kompetensi dasar dan standar kompetensi pencapaian setela siswa menyelesaikan topiktopik pembelajaran ekonomi.

Dalam kurikulum ekonomi Hong Kong terdapat sejumlah prinsip dalam pengembangan kurikulum yang mendorong guru untuk merencanakan kurikulum ekonomi secara seimbang yang memungkinkan siswa dapat berperan aktif dalam proses pembelajaran sehingga proses belajar mengajar menjadi efektif.

Dalam kurikulum ini juga terdapat sejumlah strategi pengembangan kurikulum untuk meningkatkan pendekatan yang lebih berpusat pada siswa. Strategi tersebut meliputi: (a) Mengintegrasikan pembelajaran di kelas dan belajar mandiri, (b) memperhatikan keragaman peserta didik, (c) menciptakan komunitas pembelajar di antara para siswa, (d) fleksibilias dalam pengorganisasian kelas, (e) perencanaan croscurriculer, (f) sinkronisasi konten dengan pembelajaran otentik, (g) mengintegrasikan pembelajaran dengan penilaian.

Dalam

perencanaan

kurikulum, guru diberikan panduan yang jelas dan rinci. Apa dan bagaimana merencanakan kurikulum ekonomi, digambarkan dengan jeas dalam dokumen kurikulum Hong Kong. Demikian juga halnya dalam proses pembelajaran, guru diberikan panduan secara rinci, dan bagaimana upaya guru dalam meningkatkan efektivitas dan hasil-hasil pembelajaran ekonomi, misalnya melalui penelitian tindakan kelas secara terus menerus, kolaborasi antar guru, tenaga ahli dan dinas pendidikan.

Secara umum topik atau materi pembelajaran ekonomi SMA kedua negara relatif sama. Perbedaanya terdapat pada kurikulum ekonomi Hong Kong yang membagi materi pembelajaran menjadi dua bagian yaitu bagian wajib dan pilihan. Kurikulum Ekonomi SMA Hong Kong dirancang sedemikian rupa bahwa konsep-konsep dasar dan alat analisis menjadi bagian wajib, sedangkan bagian elektif meliputi unsur-unsur pengetahuan ekonomi yang meliputi analisis lebih lanjut dan lebih luas. Siswa dapat memilih salah satu yang sesuai minat dan bakat mereka. Mereka yang tertarik dalam analisis mikroekonomi seperti strategi harga perusahaan dapat memilih Pilihan Bagian 1. sedangkan, siswa yang tertarik dalam ekonomi makro, kinerja 
dan pertumbuhan ekonomi dapat memilih pilihan 2. Kedua alternatif pilihan tersebut sudah dialokasikan waktunya. Dan pengalokasian waktu pada kurikulum ekonomi Hong Kong telah dirinci berdasarkan topik yang totalnya sebanyak 720 jam termasuk didalamnya materi pilihan sebanyak 22 jam dan disediakan juga sebanyak 54 jam untuk membahas topik-topik baru dan aktivitas penyelidikan lainnya.

Sumber belajar

dikembangkan tidak terbatas pada lingkungan sekolah, tetapi lingkungan dan masyarakat luas dapat menjadi sumber belajar. Guru sebagai fasilitator dan memberikan kemudahan akses kepada siswa dalam memperoleh sumber-sumber belajar serta mengefektifkan pemanfaatan teknologi informasi dan komunikasi.

Hal lain yang cukup menarik dalam dokumen kurikulum ekonomi SMA di Hong Kong, dicantumkan peran dan tugas setiap stakeholder, mulai dari peran dan tugas guru, peran dan tugas kepala sekolah, peran dan tugas perancang kurikulum, peran dan tugas dinas pendidikan sampai kepada peran dan tugas orang tua siswa dalam pembelajaran ekonomi.

\section{DAFTAR PUSTAKA}

Curriculum and Assessment Guide (Secondary 4 - 6). Personal, Social and Humanities Education Key Learning Area: Economics. Curriculum Development Council and the
Hong Kong Examinations and Assessment Authority

Departemen Pendidikan Nasional 2003. Standar Kompetensi Mata Pelajaran Ekonomi SMA \& MA, - Jakarta: Pusat Kurikulum, Depdiknas

Balitbang

Education and Manpower Bureau. 2004. Reforming the academic structure for senior secondary education and higher education - Actions for investing in the future. Hong Kong: Education and Manpower Bureau.

Education and Manpower Bureau. 2005. The new academic structure for senior secondary education and higher education - Action plan for investing in the future of Hong Kong.

Education Commission. 2003. Review of the academic structure of senior secondary education. Hong Kong: Education Commission.

"HKALE." Hong Kong Examination Authority. Hong Kong, 2002. Online http://www.hkea.edu.hk.

"HKCEE." Hong Kong Examination Authority. Hong Kong, 2002. Online. http://www.hkea.edu.hk. 
http://dwpkjrihongkong2.blogspot.co $\mathrm{m} / 2008 / 02 /$ pendidikan-dihong-kong.html

National Council on Economic Education.

http://www.ncee.net

National Council on Economics Education, US. Voluntary National Content Standards in Economics. Retrieved June 20, 2006, from http://www.ncee.net/ea/stan dards

New Academic Structure Handbook A Learning Journey for All Students to Succeed in the Globalised World. October 2010. Hong Kong Senior Secondary Education and Higher Education. Education Bureau Curriculum Development Institute 